\title{
How the limited recognition of WHO-approved COVID-19 vaccines harm researchers of the low-and middle-income countries - A call for action
}

\author{
Ahmed Negida' $\odot$ ब, Hazem S. Ghaith ${ }^{2} \odot$, Ulrick S Kanmounye ${ }^{3} \odot$ \\ 1 Department of Global Health and Social Medicine, Harvard Medical School; School of Pharmacy and Biomedical Sciences, University of Portsmouth; \\ Faculty of Medicine, Zagazig University; Research Department, Association of Future African Neurosurgeons, 2 Research Department, Association of \\ Future African Neurosurgeons; Faculty of Medicine, Al-Azhar University, ${ }^{3}$ Research Department, Association of Future African Neurosurgeons \\ Keywords: global health, vaccination, developing countries, health inequities \\ https://doi.org/10.52872/001c.28174
}

\section{Journal of Global Health Economics and Policy}

Vol. 1, 2021

Immunizing most of the global population with efficacious vaccines is the safest, fastest, and most reliable solution to emerge from the current COVID-19 pandemic. Extensive research efforts have produced a few vaccines with proven efficacy and acceptable safety profiles to achieve this purpose. Nonetheless, the limited manufacturing capacity and the logistics of vaccine approvals, production, shipment, and distribution to the target population, lead to significant delays that require both prioritizations of the vulnerable population groups and equitable distribution of the vaccines around the world. ${ }^{1}$

Simulations have shown that an equitable global vaccine roll-out strategy will avert twice the worldwide deaths of rolling vaccines out to high-income countries (HICs) first. ${ }^{2}$ Despite these recommendations from global health experts and the World Health Organization (WHO), it is currently estimated that more than $10 \%$ of the global population have been vaccinated. However, most of them are in HICs; the share of the population that has received at least one dose of the COVID-19 vaccine is $14 \%$ and $1 \%$ in lower-middleincome countries and low-income countries, respectively (Figure 1).

This inequitable access to vaccines has consequences and limitations on academic and clinical work in low- and middle-income countries (LMICs). Not only do some countries require proof of vaccinations to apply for travel visas, but these countries set a list of specific vaccines that are recognized by them which render individuals with other WHO-approved vaccinations ineligible.3,4 For example, people who are fully vaccinated with some vaccines including BBIBP-CorV "Sinopharm, China" and CoronaVac "Sinovac, China" are not recognized in Europe as such. Therefore, millions of vaccinated people in LMICs are barred from traveling to Europe. For example, a colleague in our team has won a competitive travel scholarship to the European Association of Neurosurgical Societies meeting 2021 in Hamburg, Germany where he is scheduled to make two presentations. However, he will not be able to travel because he did not have access to the vaccines accepted in Germany (Table 1).

In Egypt, the government successfully signed deals to secure 120 million doses of different vaccines as Sinopharm and AstraZeneca's. ${ }^{7}$ However, owing to the non-equitable

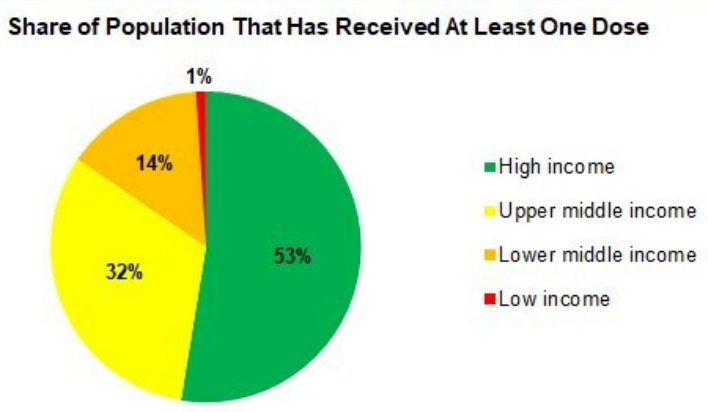

Figure 1. A Pie chart of the share of the population that has received at least one dose of COVID-19 vaccines, disaggregated by country-income level, Data as of July 7, 2021, to account for lag in-country reporting, Source: Our World in Data, World Bank, United Nations

global vaccine rollout strategy, Egypt has received only 10 million doses of its full share of COVID-19 vaccines.

Although the Sinovac and Sinopharm vaccines have been endorsed by the WHO Strategic Advisory Group of Experts and are now listed as WHO-approved COVID-19 vaccines for emergency use, European countries, United Kingdom, Canada, and other HICs still do not recognize these vaccines (Table 1).

LMICs citizens face more obstacles to resume their academic and research duties compared to their counterparts in HICs. The authors propose that all COVID-19 vaccines that meet the standards of the WHO in terms of safety and efficacy should be accepted anywhere in the world.

\section{ACKNOWLEDGEMENTS}

None

ETHICS APPROVAL

None sought 


\section{FUNDING SOURCE}

None

\section{AUTHORSHIP CONTRIBUTIONS}

All authors participated substantially in the conception of the work, drafting and revising it critically for important intellectual content, approved the manuscript to be published and have agreed to be accountable for all aspects of the work.

\section{COMPETING INTERESTS}

The authors completed the ICMJE Unified Competing Interest form at (available upon request from the corresponding author), and declare no conflicts of interest.

\section{CORRESPONDENCE}

Dr. Ahmed Negida, MBBCh Program of Global Surgery and Social Change, Department of Global Health and Social Medicine, Harvard Medical School, Boston, MA, Tel: +201125549087; ahmed_negida@hms.harvard.edu

Submitted: August 16, 2021 CET, Accepted: September 12, 2021 CET
Table 1. A list of WHO approved vaccines and their recognition in European countries, Canada, and Egypt (as an example for a lower-middle income country).

\begin{tabular}{|c|c|c|c|}
\hline $\begin{array}{l}\text { WHO } \\
\text { approved } \\
\text { vaccines }\end{array}$ & $\begin{array}{l}\text { European } \\
\text { Countries }^{5}\end{array}$ & Canada 6 & Egypt $^{7}$ \\
\hline Moderna & Approved & Approved & $\begin{array}{l}\text { Not } \\
\text { Available }\end{array}$ \\
\hline $\begin{array}{l}\text { Oxford/ } \\
\text { AstraZeneca }\end{array}$ & Approved & Approved & $\begin{array}{l}\text { Partially } \\
\text { was } \\
\text { available }\end{array}$ \\
\hline $\begin{array}{l}\text { Pfizer/ } \\
\text { BioNTech }\end{array}$ & Approved & Approved & $\begin{array}{l}\text { Not } \\
\text { Available }\end{array}$ \\
\hline $\begin{array}{l}\text { Janssen } \\
\text { vaccine }\end{array}$ & Approved & Approved & $\begin{array}{l}\text { Not } \\
\text { Available }\end{array}$ \\
\hline Sinovac & $\begin{array}{l}\text { Not } \\
\text { approved, } \\
\text { not } \\
\text { recognized }\end{array}$ & $\begin{array}{l}\text { Not } \\
\text { approved, } \\
\text { not } \\
\text { recognized }\end{array}$ & Available \\
\hline Sinopharm & $\begin{array}{l}\text { Not } \\
\text { approved, } \\
\text { not } \\
\text { recognized }\end{array}$ & $\begin{array}{l}\text { Not } \\
\text { approved, } \\
\text { not } \\
\text { recognized }\end{array}$ & Available \\
\hline
\end{tabular}




\section{REFERENCES}

1. Annex A: COVID-19 vaccine and health INEQUALITIES: Considerations for prioritisation and implementation. GOV.UK. https://www.gov.uk/govern ment/publications/priority-groups-for-coronavirus-c ovid-19-vaccination-advice-from-the-jcvi-30-decemb er-2020/annex-a-covid-19-vaccine-and-health-inequ alities-considerations-for-prioritisation-and-implem entation. Accessed September 12, 2021.

2. Estimating the effect of cooperative versus uncooperative strategies of COVID-19 vaccine allocation: A modeling study. Home. https://www.net workscienceinstitute.org/publications/estimating-th e-effect-of-cooperative-versus-uncooperative-strateg ies-of-covid-19-vaccine-allocation-a-modeling-stud y. Accessed September 12, 2021.

3. German Embassy in Cairo. Homepage, Travel \& Visa Instructions [internet]. German Embassy in Cairo Website. https://kairo.diplo.de/eg-ar. Accessed August 15, 2021.
4. Paul Ehrlich Institute; Vaccination certificate within the meaning of the COVID-19 Protective Measures Exception Ordinance and the Coronavirus Entry Ordinance [Internet. Federal Ministry of Health in Germany. https://www.pei.de/DE/newsroom/dossie $\underline{\mathrm{r} / \text { coronavirus/coronavirus-inhalt.html? } \mathrm{nn}=169730 \& \mathrm{c}}$ ms_pos $=3$. Accessed July 30, 2021.

5. PINHO AC. Covid-19 vaccines. European Medicines Agency. https://www.ema.europa.eu/en/human-regul atory/overview/public-health-threats/coronavirus-dis ease-covid-19/treatments-vaccines/covid-19-vaccine s. Published September 8, 2021. Accessed September 12, 2021.

6. Canada H. Government of Canada. COVID-19 Vaccines: Authorized vaccines - Canada.ca. https://w ww.canada.ca/en/health-canada/services/drugs-healt h-products/covid19-industry/drugs-vaccines-treatme nts/vaccines.html. Published June 2, 2021. Accessed September 12, 2021.

7. Arabic RT. Egypt's Health Secretary says Egypt has signed deals to secure 120 million doses of COVID-19 vaccines. https://ar.rt.com/qqwq. Accessed July 30, 2021. 